\title{
PRIORITAS DAN STRATEGI PENANGANAN RISIKO PRODUKSI PADA INDUSTRI TAHU DI KABUPATEN GROBOGAN
}

\author{
Suryani Nurfadillah, Kustopo Budiraharjo, Wiludjeng Roessali \\ Program Studi Agribisnis, Fakultas Peternakan dan Pertanian, Universitas Diponegoro \\ JL. Prof. H. Soedharto, S.H. Tembalang - Semarang 50275, Indonesia \\ email: suryani.nurfadillah@gmail.com
}

\begin{abstract}
The process of making tofu is more complicated and has a higher failure rate than tempe. However, tofu's gross profit which is lower than tempe, makes the tofu industry interesting. This study aimed to analyze the level of risk and priority in handling production risk in the tofu industry in Grobogan Regency, Central Java. This census study was conducted in Grobogan Regency, Central Java, in December 2019 - January 2020. Primary data were obtained by structured interviews and direct observation of 57 tofu producers in Grobogan Regency. The analytical method was the coefficient of variance (CV) to determine the level of risk and Failure Mode and Effect Analysis (FMEA) to determine the production process's potential failures and to determine the priority of risk handling. Based on the study results, the tofu industry in Grobogan Regency faced a reasonably high production risk with a CV value of $36 \%$ caused by 12 types of risk sources. Lack of clean water availability, low-quality raw materials, and imperfect clumping processes are sources of risk that need to be prioritized in managing risks. Strategies that can be taken to reduce the risk of tofu production include holding water reservoirs and water purifiers, collaborating with soybean farmer groups or cooperative, improving cleanliness, implementing SOPs, increasing worker supervision, periodic inspection and maintenance of machines, and bringing boiling places closer to the mold area.
\end{abstract}

Keywords: CV, FMEA, production risk, tofu

\section{PENDAHULUAN}

Olahan kedelai berupa tahu dan tempe merupakan jenis lauk yang paling sering terhidang di meja makan keluarga Indonesia, terutama di Pulau Jawa. Konsumsi tempe ratarata per kapita di Indonesia menurut data Susenas BPS (2016) diperkirakan sebesar 20,2 gram per hari, lebih rendah sedikit dari konsumsi tahu yakni 21,6 gram per kapita per hari. Selain karena kaya akan protein, harganya yang lebih murah dibanding sumber protein hewani seperti telur atau daging, menjadikan olahan kedelai ini diminati masyarakat. Di masa mendatang, permintaan terhadap kedelai ini diprediksi akan terus mengalami peningkatan yang cukup signifikan dan berbanding lurus dengan pertambahan jumlah penduduk di Indonesia (Tayono, 2014). Peningkatan permintaan akan tahu dan tempe juga seiring dengan meningkatnya kesadaran akan kesehatan sehingga konsumsi masyarakat mulai beralih ke pangan non-hewani (Hanafi et al., 2014). Bahkan seperti yang banyak diberitakan, tahu dan tempe mulai banyak digemari negara-negara tetangga seperti Malaysia dan Jepang.

Hal yang menarik dari keberadaan industri tahu dan tempe adalah skala industrinya yang kebanyakan masih berupa industri kecil dan menengah yang berproduksi dengan metode tradisional, padahal daya beli masyarakat untuk produk ini relatif tinggi (Hara et al., 2017). 
Masalah utama yang ditemui dalam produksi tahu dan tempe ialah bahan bakunya yang didominasi oleh pasokan kedelai dari negaranegara lain (Facino, 2012). Ketergantungan terhadap kedelai impor ini menyebabkan industri tahu rawan terdampak fluktuasi harga. Sedangkan apabila menggunakan kedelai lokal, maka akan mempengaruhi kualitas tahu dan berdampak pada turunnya penjualan akibat kurang sesuai dengan selera pasar.

Usaha tahu dan tempe memiliki kelebihan dan kekurangan masing-masing. Volume produksi tahu biasanya 2-3 kali lebih besar dibanding tempe. Selain itu, berbeda dengan tahu yang bisa diproses dan dijual di hari yang sama, tempe memerlukan waktu 3-4 hari untuk proses fermentasi sebelum siap dijual. Dilihat dari sisi modal, modal yang dibutuhkan pabrik tempe juga lebih sedikit karena hanya memerlukan modal bahan pembungkus berupa plastik atau daun, ragi, dan alat yang tidak semahal pabrik tahu. Sementara itu untuk Tabel 1 Sebaran pengerajin tahu di Kabupaten Grobogan

\begin{tabular}{|c|c|c|}
\hline No & Kecamatan & Jumlah Produsen \\
\hline 1 & Purwodadi & 3 \\
\hline 2 & Grobogan & 0 \\
\hline 3 & Pulokulon & 2 \\
\hline 4 & Geyer & 0 \\
\hline 5 & Toroh & 11 \\
\hline 6 & Wirosari & 2 \\
\hline 7 & Kradenan & 39 \\
\hline 8 & Gabus & 0 \\
\hline
\end{tabular}

Sumber: Bagian Perekonomian Setda Kabupaten Grobogan, 2017

memproduksi tahu, pengrajin butuh lebih banyak karyawan dan peralatan khusus. Terakhir, laba kotor dari produksi tahu berkisar $15 \%-25 \%$ dari penjualan, sementara laba kotor tempe bisa mencapai $50 \%$ dari penjualan (Safitra, 2013; Holle, 2014; Ningsih et al, 2017). Proses pembuatan tahu yang lebih rumit dibanding tempe namun memiliki laba kotor yang lebih rendah membuat industri tahu menarik untuk diteliti. Penelitian ini bertujuan untuk menganalisis tingkat risiko dan prioritas penanganan risiko produksi pada industri tahu di Kabupaten Grobogan, Jawa Tengah.

\section{METODE}

Penelitian ini dilakukan di Kabupaten Grobogan, Jawa Tengah pada Desember 2019 Januari 2020. Metode yang digunakan dalam penelitian ini adalah sensus. Data primer diperoleh dengan wawancara terstruktur dan pengamatan langsung kepada seluruh pengrajin tahu di Kabupaten Grobogan, yakni sebanyak 57 pengrajin yang tersebar di 5 kecamatan.

\footnotetext{
Penelitian ini menggunakan metode analisis
deskriptif kuantitatif. Data yang telah diperoleh

Penelitian ini menggunakan metode analisis
deskriptif kuantitatif. Data yang telah diperoleh

kemudian ditabulasi dan dianalisis serta dibandingkan dengan literatur yang ada.
} 
Analisis deskriptif dilakukan untuk menjelaskan gambaran umum usaha, jenis risiko, dan pelaksanaan manajemen risiko dalam produksi tempe. Sedangkan analisis kuantitatif untuk mengukur besarnya risiko dilakukan dengan menghitung standar deviasi dan koefisian varians yang dihitung dengan rumus:

$$
\begin{gathered}
\sigma^{2}=\sum_{\mathrm{i}=1}^{n}(\mathrm{Q} \mathrm{i}-\mathrm{E}(\mathrm{Q}))^{2} \\
\sigma=\sqrt{ } \sigma^{2} \\
\mathrm{KV}=\frac{\sigma}{\mathrm{E}(Q)} \times 100 \%
\end{gathered}
$$

Keterangan:

$\sigma^{2}=$ Varians

$\sigma \quad=$ Simpangan baku

$$
\mathrm{E}(\mathrm{Q}) \quad=\text { Expected return }
$$

Qi = Produksi tempe

$\mathrm{KV}=$ Koefisien varians

Selain standar deviasi dan koefisian varians, analisis Failure Mode and Effect Analysis (FMEA) digunakan untuk menganalisis potensi kegagalan dalam suatu proses produksi. Identifikasi sumber-sumber risiko dilakukan dengan melakukan wawancara kepada beberapa narasumber yang berhubungan langsung dengan proses pengolahan tahu. Dalam penelitian ini, penentuan sumber risiko dilakukan oleh pemilik/pekerja yang mengetahui persis atau sudah terbiasa melakukan proses produksi. Potensi yang teridentifikasi akan diklasifikasikan menurut besarnya potensi kegagalan dan efeknya terhadap proses proses produksi. Metode analisis FMEA dilakukan dengan cara menilai tingkat dampak (severity), menilai tingkat kemungkinan terjadi (occurance), dan menilai tingkat kemungkinan deteksi (detectibility) berdasarkan skala penilaian yang telah ditetapkan (1-10). Kemudian menghitung tingkat prioritas risiko pada setiap permasalahan yang ditemukan berdasarkan nilai Risk Priority Number (RPN) dengan rumus sebagai berikut (Stamatis, 1995):

$$
R P N=S . O . D
$$

Keterangan:

$\mathrm{S}=$ Nilai Severity

$\mathrm{O}$ = Nilai Occurance

D = Nilai Detection

\section{HASIL DAN PEMBAHASAN}

\section{Proses Pembuatan Tahu}

Proses pembuatan diawali dengan perendaman kedelai selama 3 - 4 jam dengan perbandingan kedelai dengan air sebanyak 5 10 lt air per $1 \mathrm{~kg}$ kedelai. Selanjutnya kedelai yang sudah direndam kemudian dicuci dan digiling sampai halus hingga menghasilkan ampas dan sari kedelai. Sari kedelai direbus menggunakan steam boiler hingga mendidih $( \pm$ 20 - 30 menit) sambil diaduk perlahan secara terus-menerus. Selanjutnya adalah proses penggumpalan dengan penambahan air biang (sisa air perebusan sari kedelai yang telah terpisah ditambah cuka makan) dan kemudian diaduk perlahan sampai menggumpal selama kurang lebih 30 menit sehingga dengan sendirinya sari kedelai akan terpisah menjadi santan tahu dan air. Setelah itu santan tahu yang sudah menggumpal dituangkan ke dalam 
cetakan, diratakan, dan ditutup dengan kain saring kemudian ditindih dengan beban agar semua air keluar. Selanjutnya didiamkan hingga padat $( \pm 1$ jam), kemudian tahu siap dipotong.

\section{Profil Industri Tahu}

Berdasarkan hasil wawancara terhadap 57 pengrajin tahu di Kabupaten Grobogan, diketahui bahwa seluruh usaha pembuatan tahu di Kabupaten Grobogan masih berskala kecil dengan rata-rata kapasitas produksi di bawah $250 \mathrm{~kg}$ bahan baku setiap bulannya. Tenaga kerja yang digunakan dalam bervariasi antara 58 orang per usaha produksi tahu. Setiap bulannya, struktur biaya yang dikeluarkan pengrajin tahu adalah bahan baku sebesar $67 \%$, upah tenaga kerja sebesar $16 \%$, penyusutan peralatan sebesar $13 \%$, serta biaya lain-lain (biaya listrik, bahan bakar, dan kemasan plastik) sebesar 3\% dari total biaya produksi.

Sebanyak $54 \%$ pengrajin tahu masih menggunakan kedelai jenis impor sebagai bahan baku utama, sedangkan sisanya menggunakan kedelai local varietas Grobogan. Penggunaan kedelai impor oleh sebagian besar pengrajin disebabkan karena kedelai impor memiliki harga yang lebih murah dan kualitas yang dipandang lebih baik daripada kedelai lokal. Kedelai impor memiliki ukuran yang lebih besar dan seragam, serta kulit ari yang mudah dipisahkan. Hal ini bertolakbelakang dengan Ginting et al. (2009) yang menyatakan bahwa kedelai lokal unggul dari impor dalam hal bahan baku pembuatan tahu karena membuat rasa tahu lebih lezat, memiliki rendemennya lebih tingi, dan resiko terhadap kesehatan cukup rendah karena bukan benih transgenik.

Sebanyak $32 \%$ pengrajin tahu juga memiliki usaha produksi tempe. Mereka tidak membeli kedelai di satu tempat tanpa membedakan jenis kedelai untuk bahan baku pembuatan tahu dan tempe. Hal ini juga menjadi alasan sebagian besar pengrajin menggunakan kedelai impor, karena dibutuhkan kedelai dengan ukuran yang relatif besar, seragam untuk pembuatan tempe. Produksi tahu memiliki hasil sampingan berupa ampas yang biasa digunakan sebagai bahan makanan ternak sehingga masih memiliki nilai ekonomi. Tiap 100 kg kedelai, menghasilkan ampas tahu sebanyak 5 karung yang dapat dijual dengan harga Rp 11.000/karung.

\section{Pengukuran Tingkat Risiko}

Risiko dapat didefinisikan sebagai peluang hilangnya atau hasil yang tidak menguntungkan terkait dengan suatu tindakan yang disebabkan ketidakpastian mengenai apa yang akan terjadi di masa depan. Sedangkan risiko produksi berasal dari ketidakpastian faktor-faktor produksi yang memengaruhi kuantitas dan kualitas hasil (Crane, 2013).

Berdasarkan Tabel 2 diketahui bahwa ratarata kebutuhan bahan baku per bulan adalah sebesar 247,37 kg kedelai dan menghasilkan $585,44 \mathrm{~kg}$ tahu. Hal ini berarti dari $1 \mathrm{~kg}$ kedelai dapat menghasilkan 2,38 kg tahu. Rendemen sebesar $238 \%$ tersebut masih lebih rendah dibanding standar yang menyatakan umumnya rendemen pada industri tahu bervariasi antara 264\%-376\% (Andarwulan et al., 2018; Syah et 
al., 2015). Selanjutnya diketahui KV dari rendemen sebesar $36 \%$ yang menggambarkan tingkat risiko produksi tahu. Semakin tinggi nilai KV maka semakin besar pula risiko yang dihadapi. Berdasarkan standar rendemen dan nilai $\mathrm{KV}$ dapat disimpulkan bahwa risiko produksi yang dihadapi pengrajin tahu di Kabupaten Grobogan termasuk tinggi.

\section{Tingkat Prioritas dan Strategi indikator risiko produksi.}

Setelah diketahui tingkat risiko, maka dapat ditentukan tingkat prioritas penanganan sehingga dapat dilakukan proses pengendalian sesuai dengan urutan dampak yang dihasilkan oleh risiko tersebut. Untuk menentukan tingkat risiko produksi yang memiliki tingkat urgensi paling tinggi dengan cara menghitung nilai RPN yang dimiliki oleh masing-masing

Tabel 2 Tingkat risiko produksi (KV) industri tahu di Kabupaten Grobogan

\begin{tabular}{clr}
\hline No & \multicolumn{1}{c}{ Variabel } & Nilai \\
\hline 1 & Kebutuhan bahan baku per bulan $(\mathrm{kg})$ & 247,37 \\
2 & Hasil produksi tahu per bulan $(\mathrm{kg})$ & 585,44 \\
3 & Rendemen tahu & 2,38 \\
4 & Simpangan baku & 0,87 \\
5 & Koefisien varians & 0,36 \\
\hline
\end{tabular}

Tabel 3 Tingkat prioritas risiko

\begin{tabular}{|c|c|c|c|c|c|c|}
\hline $\mathrm{o}$ & Sumber Risiko & $\mathrm{S}$ & $\mathrm{O}$ & $\mathrm{D}$ & RPN & Peringkat \\
\hline & Kurangnya ketersediaan pasokan baku kedelai & 5,63 & 3,91 & 3,55 & 78,15 & 4 \\
\hline & Kualitas bahan baku yang rendah & 5,45 & 3,36 & 6,73 & 123,24 & 2 \\
\hline & Harga bahan baku kedelai fluktuatif & 3,09 & 3,00 & 5,64 & 52,28 & 8 \\
\hline & $\begin{array}{l}\text { Sortasi kedelai yang kurang bersih sehingga masih ada } \\
\text { kedelai busuk atau sampah yang masuk }\end{array}$ & 6,54 & 3,64 & 2,73 & 64,99 & 5 \\
\hline & Kurangnya ketersedian air bersih & 7,72 & 3,27 & 5,63 & 142,13 & 1 \\
\hline & Kurang halusnya penggilingan sari tahu & 4,36 & 3,55 & 2,91 & 45,04 & 10 \\
\hline & Kerusakan mesin dan peralatan pada proses produksi & 4,09 & 4,45 & 2,32 & 42,23 & 11 \\
\hline & Kurangnya kebersihan selama proses produksi & 4,91 & 5,36 & 2,25 & 59,21 & 7 \\
\hline & Tumpahnya santan tahu saat akan dituang ke cetakan & 4,01 & 3,18 & 2,73 & 34,81 & 12 \\
\hline 0 & Proses penggumpalan yang tidak sempurna & 5,12 & 4,91 & 3,36 & 84,47 & 3 \\
\hline 1 & Hancurnya tahu saat pengemasan & 4,09 & 3,91 & 3,86 & 61,73 & 6 \\
\hline 2 & Kelalaian pekerja & 4,45 & 4,25 & 2,45 & 46,34 & 9 \\
\hline
\end{tabular}

Berdasarkan observasi dan wawancara kepada pemilik usaha mapun karyawan produksi, diketahui terdapat 12 indikator risiko yang umum terjadi pada proses produksi tahu (Tabel 3).

Berdasarkan Tabel 3 diketahui bahwa kurangnya ketersediaan air bersih menjadi sumber risiko dengan nilai RPN paling besar 
sehingga menempati peringkat 1 , disusul oleh kualitas bahan baku yang rendah, dan proses penggumpalan yang tidak sempurna. Nilai RPN yang tinggi mengindikasikan bahwa risiko tersebut perlu menjadi prioritas dalam penanganan risiko. Sedangkan sumber resiko yang memiliki RPN paling kecil adalah tumpahnya santan tahu saat akan dituang ke cetakan.

Air bersih merupakan faktor krusial dalam pembuatan tahu, terutama saat proses perebusan. Apabila air yang digunakan kurang bersih, maka tahu yang dihasilkan akan memiliki aroma dan rasa yang masam. Selain itu dengan penggunaan air yang kurang bersih, tahu yang dihasilkan biasanya mudah hancur. Konsumen tidak menyukai tahu yang masam dan mudah hancur, sehingga apabila tahu yang dihasilkan ternyata memiliki karakteristik tersebut maka tidak akan laku terjual.

Kualitas bahan baku yang rendah menjadi risiko dengan prioritas penanganan kedua. Hasil produksi yang berbeda-beda pada setiap periode produksi merupakan risiko yang dihadapi oleh setiap pengelola usaha pengolahan. Hal ini disebabkan karena bahan baku yang berasal dari bidang pertanian dipengaruhi oleh banyak faktor yang sulit dikendalikan oleh petani (Drollette, 2009). Terdapat beberapa faktor yang mempengaruhi kualitas kedelai, misalnya kedelai yang dipanen terlalu cepat maupun terlalu tua, memiliki kadar air yang tinggi, serta kedelai dalam kondisi yang kotor. Umur panen kedelai akan mempengaruhi kualitas tahu yang dihasilkan, seperti warna dan rasa. Sedangkan kadar air dan kotoran yang tercampur lebih mempengaruhi kuantitas yang dihasilkan.

Sebanyak $58 \%$ pengrajin tahu Kabupaten Grobogan biasa membeli kedelai sebagai bahan baku pembuatan tahu dari pedagang besar, 33\% pengrajin membeli dari Koperasi Industri Tahu Tempe Indonesia (KOPTI), dan 9\% membeli kedelai di pasar. Menurut para pengrajin, kualitas kedelai yang dibeli dari KOPTI memang relatif lebih baik dan seragam, namun sebagian besar pengrajin memilih membeli dari pedagang besar karena lebih murah, pasokannya stabil, dan terdapat kemudahaan pembayaran yang disebabkan faktor kedekatan personal.

Kualitas bahan baku juga ditentukan oleh frekuensi pembelian. Kedelai yang disimpan terlalu lama maka kualitasnya akan turun. Terlebih lagi apabila ada kedelai yang busuk, maka akan mudah menyebar dan menyebabkan kerusakan kedelai lainnya. Frekuensi pembelian bahan baku oleh masing-masing pengrajin cukup bervariasi dari mulai setiap hari, 1 minggu, maupun setiap 2 minggu. Mayoritas (49\%) pengrajin membeli bahan baku setiap 1 minggu. Pengrajin yang memilih membeli kedelai setiap hari $(32 \%)$ berasalan karena dengan memasok dalam jumlah yang tidak terlalu besar akan memudahkan untuk mengontrol kualitas bahan baku. Sedangkan pengrajin yang memilih membeli setiap 2 minggu (19\%) beralasan karena merasa kerepotan jika harus berkali-kali melakukan 
pembelian, sehingga mereka memilih menyimpan stok dalam jumlah besar.

Risiko dengan prioritas penanganan ketiiga adalah proses penggumpalan yang tidak sempurna. Penggumpalan yang tidak sempurna ini dapat disebabkan oleh beberapa hal seperti kualitas bahan baku, pencucian kedelai yang kurang bersih, dan kualitas air biang. Namun, menurut para pengrajin tahu, tidak

Tabel 4 Strategi Penanganan Risiko

\begin{tabular}{|c|c|c|}
\hline Peringkat & Sumber Risiko & Strategi penanganan \\
\hline 1 & Kurangnya ketersedian air bersih & $\begin{array}{l}\text { 1. Memiliki atau menambah tandon air } \\
\text { 2. Memasang penjernih air }\end{array}$ \\
\hline 2 & Kualitas bahan baku yang rendah & $\begin{array}{l}\text { Menjalin kerjasama (contractual arrangements) } \\
\text { dengan kelompok tani kedelai atau KOPTI }\end{array}$ \\
\hline 3 & Proses penggumpalan yang tidak sempurna & Selalu menggunakan air biang yang baru \\
\hline 4 & $\begin{array}{l}\text { Kurangnya ketersediaan pasokan baku } \\
\text { kedelai }\end{array}$ & $\begin{array}{l}\text { 1. Menjalin kerjasama (contractual } \\
\text { arrangements) dengan kelompok tani kedelai } \\
\text { atau KOPTI } \\
\text { 2. Input reserve }\end{array}$ \\
\hline 5 & $\begin{array}{l}\text { Sortasi kedelai yang kurang bersih } \\
\text { sehingga masih ada kedelai busuk atau } \\
\text { sampah yang masuk }\end{array}$ & $\begin{array}{l}\text { 1. Meningkatkan pengecekan terhadap bahan } \\
\text { baku yang masuk } \\
\text { 2. Mencuci kedelai dengan air yang mengalir }\end{array}$ \\
\hline 6 & tahu saat pengemasan & $\begin{array}{l}\text { 1. Memastikan tahu terpotong sampai dasar } \\
\text { 2. Meningkatkan kehati-hatian saat mengemas }\end{array}$ \\
\hline 7 & ya kebersihan selama proses & $\begin{array}{l}\text { Mewajibkan pekerja membersihkan tempat } \\
\text { produksi setiap hari sebelum pulang }\end{array}$ \\
\hline 8 & han baku kedelai fluktuatif & $\begin{array}{l}\text { 1. Menjalin kerjasama (contractual } \\
\text { arrangements) dengan kelompok tani kedelai } \\
\text { atau KOPTI } \\
\text { 2. Input reserve }\end{array}$ \\
\hline 9 & & Penerapan SOP dan peningkatan pengawasan \\
\hline 10 & lusnya penggilingan $\mathrm{s}$ & $\begin{array}{l}\text { 1. Mematuhi SOP dalam penggilingan (baik } \\
\text { cara maupun lama penggilingan) } \\
\text { 2. Selalu membersihkan mesin penggiling } \\
\text { setelah digunakan }\end{array}$ \\
\hline 11 & $\begin{array}{l}\text { Kerusakan mesin dan peralatan pada } \\
\text { proses produksi }\end{array}$ & Pemeriksaan dan perawatan mesin secara berkala \\
\hline 12 & $\begin{array}{l}\text { Tumpahnya santan tahu saat akan dituang } \\
\text { ke cetakan }\end{array}$ & $\begin{array}{l}\text { Mengurangi jarak antara tempat perebusan } \\
\text { dengan cetakan }\end{array}$ \\
\hline
\end{tabular}

Setelah mengetahui risiko mana yang harus diprioritaskan untuk ditangani, perlu diformulasikan strategi yang dapat dilakukan sempurnanya penggumpalan ini mayoritas disebabkan oleh kualitas air biang. Air biang merupakan sisa air perebusan sari kedelai yang telah terpisah ditambah cuka makan. Apabila air biang yang digunakan sudah lama atau tercampur dengan bahan lain maka akan menurunkan kualitasnya dan menyebabkan proses penggumpalan menjadi tidak sempurna.
1. Memiliki atau menambah tandon air

2. Memasang penjernih air dengan kelompok tani kedelai atau KOPTI

Selalu menggunakan air biang yang baru

(contractual arrangements) dengan kelompok tani kedelai

- Meningkatkan pengecekan terhadap bahan gasuk

Mencuci kedelai dengan air yang mengalir

1. Memastikan tahu terpotong sampai dasar

2. Meningkatkan kehati-hatian saat mengemas

Mewajibkan pekerja membersihkan tempat

Menjalin kerjasama (contractual arrangements) dengan kelompok tani kedelai

. Input reserve

Penerapan SOP dan peningkatan pengawasan

. Mematuhi SOP dalam penggilingan (baik cara maupun lama penggilingan)

. Selalu membersihkan mesin penggiling setelah digunakan

Mengurangi jarak antara tempat perebusan
dengan cetakan untuk meminimalisir risiko produksi (Tabel 4). Risiko yang disebabkan karena kurangnya ketersediaan air bersih dapat ditanggulangi 
dengan mengadakan tandon air untuk menyimpan air dan memasang penjernih/saringan air. Namun tentunya aplikasi strategi ini akan berimplikasi pada peningkatan biaya.

Pengrajin tahu juga perlu menjalin kerjasama (contractual arrangements) dengan kelompok tani kedelai atau KOPTI sebagai strategi untuk menjamin pasokan bahan baku. Strategi tersebut secara tidak langsung akan meminimalisir risiko produksi yang disebabkan oleh kualitas bahan baku yang rendah, kurangnya ketersediaan pasokan baku kedelai, dan harga bahan baku kedelai fluktuatif. Namun contractual arrangements saja tidak cukup untuk menjamin bahan baku dari segi ketersediaan dan harga, akan tetapi perlu didukung dengan strategi input reserve atau dengan memiliki cadangan bahan baku sebagai persediaan.

Peningkatan kebersihan juga menjadi strategi yang perlu dilakukan untuk mengurangi risiko pada produksi tahu. Pekerja dihimbau untuk selalu mencuci kedelai dengan air yang mengalir, menggunakan air biang yang baru, membersihkan mesin penggiling setelah digunakan, dan membersihkan seluruh bagian tempat produksi sebelum pulang setiap harinya. Namun hal-hal tersebut perlu diikuti dengan penerapan SOP dan peningkatan pengawasan dari pemilik supaya dapat berjalan dengan efektif.

Pekerja perlu lebih hati-hati dalam memotong dan mengemas tahu untuk mengurangi risiko hancurnya tahu saat pengemasan. Selain itu, kebiasaan memotong tahu yang tidak sampai dasar menyebabkan ada bagian tahu yang tertinggal sehingga bentuknya akan menjadi jelek. Kebiasaan tersebut juga perlu diperbaiki sehingga tahu yang dihasilkan tetap bagus dan tidak mengurangi nilai jualnya. Kerusakan mesin dan peralatan pada proses produksi dapat diminimalisir dengan pemeriksaan dan perawatan mesin secara berkala. Strategi lain yang perlu diterapkan adalah dengan mendekatkan tempat perebusan santan tahu dengan cetakan supaya dapat mengurangi risiko tumpahnya santan tahu saat akan dituang ke cetakan.

\section{KESIMPULAN}

Industri tahu di Kabupaten Grobogan menghadapi risiko produksi yang cukup tinggi. Kurangnya ketersediaan air bersih, kualitas bahan baku yang rendah, dan proses penggumpalan yang tidak sempurna menjadi sumber resiko yang perlu mendapat prioritas dalam penanganan risiko. Strategi yang dapat dilakukan untuk mengurangi risiko pada produksi tahu antara lain mengadakan tandon air dan penjernih air, menjalin kerjasama dengan kelompok tani kedelai atau KOPTI, meningkatkan kebersihan, menerapkan SOP, meningkatkan pengawasan terhadap pekerja, pemeriksaan dan perawatan mesin secara berkala, serta mendekatkan tempat perebusan santan tahu dengan cetakannya.

\section{DAFTAR PUSTAKA}

Andarwulan, N., L. Nuraida, D. R. Adawiyah, R. N. Triana, D. Agustin, D. Gitapratiwi. 
2018. Pengaruh Perbedaan Jenis Kedelai terhadap Kualitas Mutu Tahu. Jurnal Mutu Pangan 5(2): 66-72.

Bagian Perekonomian Setda Kabupaten Grobogan. 2017. Data Produsen (IKM) Tahu / Tempe Tahun 2015 Kab. Grobogan.

http://pojokperekonomian.grobogan.go.i $\mathrm{d} /$ images/industri daerah/DATA_IKM\%20TAHU_TEMP E_KAB_GROBOGAN.pdf

[BPS] Badan Pusat Statistik. 2016. Pengeluaran untuk Konsumsi Penduduk Indonesia, Susenas Maret 2016. BPS. Jakarta.

Crane, L., G. Gantz, S. Isaacs, D. Jose, and R. Sharp. 2013. Introduction to Risk Management. Extension Risk Management Education and Risk Management Agency, USDA.

Drollette, S. A. 2009. Understanding Agricultural Risk. Department of Applied Economics. Utah State University.

Facino, A. 2012. Penawaran Kedelai Dunia dan Permintaan Impor Kedelai Indonesia serta Kebijakan Perkedelaian Nasional. Skripsi. Institut Pertanian Bogor.

Hanafi, F.I., Daris, E., dan Rochaeni, S. 2014. Analisis Faktor-Faktor yang Mempengaruhi Permintaan Tempe di Kelurahan Jurangmangu Timur, Pondok Aren, Tangerang Selatan. Jurnal Agribisnis 8 (1): 45-58.

Hara, S., R. M. Kumaat, P. A. Pangemanan, dan M. L. Sondakh. 2017. Profil Industri Rumah Tangga Tahu Tempe "X" di
Kelurahan Bahu Kecamatan Malalayang. Agri-SosioEkonomi Unsrat, 13(2): 107 116. Jurnal Pendidikan Ekonomi 2(3): 1 15.

Holle, F. R. 2014. Pengembangan Industri Kecil Tahu pada Sentral Industri Tahu dan Tempe Desa Sepande Kecamatan Candi Kabupaten Sidoarjo.

Ningsih, O., A. Harahap, dan T. Indrawati. 2017. Dampak Kenaikan Harga Kedelai Terhadap Industri Tahu dan Tempe di Kota Pekanbaru. JOM Fekon 4(1): 995 1003.

Safitra, M. N. 2013. Analisis Faktor-Faktor yang Mempengaruhi Produksi Industri Tahu dan Tempe di Kota Makassar. Skripsi. Hasanuddin Makassar.

Stamatis, D. H. 1995. Failure Mode and Effect Analysis: FMEA from Theory to Execution. Milwaukee (US): ASQC Quality Press

Syah D, A. B. Sitanggang, R. H. F Faradilla, Trisna V, Karsono Y, dan D. A. Septianita. 2015. The influence of coagulation conditions and storage proteins on the textural properties of soy curd. CyTA-J Food 13(2): 259-263.

Tanoyo, S. B. 2014. Analisis Dampak Kenaikan Harga Kedelai Terhadap Pendapatan Usaha Pengrajin Tempe Skala Kecil dan Rumah Tangga (Kasus Kelurahan Krobokan, Kecamatan Semarang Barat, Kota Semarang). Skripsi. Universitas Diponegoro. 